\title{
Report on the Tunicata of Plymouth.
}

\author{
By
}

Walter Garstang, M.A.,

Jesus College, Oxford;

Berkeley Fellow of The Owens College, Manchester.

With Plate II.

\section{PART I._CLAVELINID $A ，$ PEROPHORID $A ，$ DIAZONID $A$.}

THe southern shores of the English Channel have long been famous for the wealth of their Tunicate fauna, having furnished material in abundance for the classical researches of Milne-Edwards, Giard, and Lacaze-Duthiers. The Channel Islands also have been repeatedly visited by English zoologists, and have amply supplied those among them who have been in search of Tunicate treasures. Probably the peculiar tidal conditions of this part of the Channel are especially favourable to a rich development of littoral forms; but, as the work of Montagu, Couch, Clark, Alder, Gosse, Cocks, Bate, and Norman sufficiently testifies, the Devon and Cornish coasts of England can lay claim to an almost equally luxuriant shore fauna, the rocky bays and long sheltered estuaries being especially wealthy in this respect. During my residence at Plymouth I found that the Tunicata were among the best represented groups of the fauna, and, as I devoted considerable attention to the search for rare or new, as well as for well-known forms, I trust that a classified report upon the local representatives of the group will not be without its usefulness to other investigators.

The absence of any work at all approaching the character of a monograph of the British Tunicata is a serious want which has long been felt by marine zoologists generally. Such a work has several times been commenced by some of our most. eminent 
naturalists, by Forbes and Goodsir, by Alder and Hancock, and by Professor Huxley; but various causes have hitherto conspired to delay its production. It is now very satisfactory to be assured that the preparation of the Monograph is in the hands of the experienced author of the Reports on the "Challenger" Tunicata. In the meantime a more or less detailed account of the forms with which I have met at Plymouth may be of some service as a contribution towards an improved knowledge of the British representatives of the group.

In the neighbourhood of Plymouth I found the rocks under the Hoe, the north and east sides of Drake's Island, the wooden piles of the docks and wharves in Millbay and the Cattewater, the rocks and tidal pools of the Mewstone and Wembury Bay, to be all good hunting-grounds for the littoral species of composite Tunicata; the best dredging-grounds for Ascidians generally were undoubtedly the neighbourhood of the Duke Rock, the Queen's Grounds, and the deeper waters off the Eddystone, the Mewstone, and Bigbury Bay, while some forms were most common upon Zostera in Cawsand Bay; but it was almost impossible to use any of the ordinary methods of collecting within Plymouth Sound without obtaining numbers of Ascidians of various species. Very few simple Ascidians were to be found inhabiting the tidal zone; they were most plentiful in the deep water of the trawling grounds and on the rough ground off the Mewstone.

In reporting upon the Ascidians of Plymouth, I have taken Clavelina and its allies as my starting-point, since this genus includes the forms which are in many respects probably the least modified descendants of the earliest Ascidiacea. But I am met at the outset by the problem which is now engaging the attention of every Ascidiologist: What taxonomical value must be attributed to the possession of the power of budding and of the formation of colonies? A full discussion of this question I cannot give here, but since the matter bears directly upon the classification which I shall employ, I am bound to admit that the division of the Ascidiacea into the suborders Ascidiæ simplices, Ascidiæ compositæ, and Ascidiæ salpiformes so completely disregards the admitted inter-relationship between various sections of these groups, that its adoption seems to me to involve the rejection of any morphological, and therefore genetic, meaning in classification altogether. The term "composite Ascidians" is in practice a very convenient one, but this is not a sufficient reason for retaining it as the symbol of a natural group, when the group in question is in reality no natural group at all, but an "artificial assemblage" composed of several quite unrelated phyla. The primary subdivision of the Ascidiacea into these three 
sub-orders will therefore not be adopted in my Report; the various genera will be grouped into families upon morphological grounds pure and simple, and will be taken as far as possible in the order of their affinity. From the nature of the case it is impossible to do this with perfect satisfaction, because the families of Tunicates, as of other orders of animals, do not form a single series; but upon completing the description of the species I will present a scheme of classification in which the various families will be bound together according to their most probable phylogenetic relationships.

I desire here to express my warm thanks to Professor Herdman for the assistance which he has liberally given me from time to time ; as regards the present paper, I am particularly indebted to him for his kindness in rendering me various information concerning still unpublished work of his upon members of the Clavelinidx and upon Tunicate classification* generally. I am equally indebted to Professor Milnes Marshall for the excellent facilities and help which he has afforded me in his Laboratories.

\section{Order ASCIDIACEA.}

\section{Family 1.-CLA VELINID A.}

Body consisting of a thorax and abdomen connected by a slender, more or less elongate, œsophageal region. Stolonial tubes arising from the posterior end of the abdomen, rarely from its lateral walls.

Test gelatinous or cartilaginous; forming either distinct sheaths round the stolonial tubes or a common mass investing them ; common test never extending above the abdominal region ; apertures circular, not lobed, placed near together, terminal.

Musculature consisting almost exclusively of longitudinal bundles ; transverse muscles rare.

Branchial sac not folded; horizontal membranes well developed, without papillæ or internal longitudinal bars; dorsal lamina consisting of a series of languettes flattened antero-posteriorly and continuous with the horizontal membranes; stigmata straight.

Tentacles simple, filiform.

Genitalia in the loop of the intestine; oviduct and vas deferens present.

Reproduction by gemmation as well as from ova.

The family, as thus defined, includes the genera Clavelina

* Professor Herdman's views upon the classification of the Tunicata will form the subject of a comprehensive memoir in the Transactions of the Linnæan Society, to which Society they were recently communicated.

NEW SERIES.-VOL. II, NO. I. 
(Savigny), Podoclavella (Herdman), Stereoclavella (Herdman), and a new genus, Pycnoclavella, described below.

I believe there is abundant reason for dividing the family Clavelinidæ, as regarded by Herdman, into several groups; Perophora, indeed, was excluded by Giard in 1872 and by von Drasche in 1883, while still more recently Lahille (1890) has emphasised the differences between Clavelina and Perophora by placing the former genus in the Distomidæ and the latter in the Ascidiidæ. Von Drasche's family Clavelinidæ includes Diazona, but although a near relationship between Clavelina and Diazona is generally admitted, it must be remembered that the new forms discovered in recent years have rather emphasised than reduced the gap between the two genera; I have therefore excluded Diazona from the Clavelinidæ altogether. As above defined, this family includes a number of forms about whose close mutual affinity there can be no doubt.

\section{Chavelina, Savigny.}

Ascidia, O. F. Mïller. Zoologia Danica, vol. ii, 1788. In part.

- Bruguière. Hist. Nat. des Vers, Encycl. Méthodique, Paris, 1792, p. 141. In part.

- Turton. Linné's General System of Nature, London, 1802, vol. iv, p. 92. In part.

Clanblina, Savigny. Mémoires sur les Animaux sans Vertèbres, Paris, 1816, IIe Partie, pp. 87 and 109. In part.

- Savigny. Tableau systématique des Ascidies, p. 171. In part.

- Fleming. Molluscous Animals, Edinburgh, 1837, p. 202. In part.

- M. Edwards. Observations sur les Ascidies des Côtes de la Manche Mém. de l'Acad. des Sci., Paris, xviii, 1842, p. 50. In part.

Claveluina, Alder. Cat. Moll. of Northumberland and Durham, Trans. Tyneside Nat. Field Club, 1848, p. 108.

Cunveuina, Forbes and Hanley. Hist. Brit. Moll., i, 1853, p. 26.

Claveluina, Adams. Genera of Recent Mollusca, London, 1858, vol, ii, p. 595. In part.

Clavelina, Giard. Recherches sur les Synascidies, Arch. Zool. Exp., i, 1872, p. 613.

Herdman. Prelim. Report on Tunicata of "Challenger," Proc. Roy. Soc. Edin., x, 1880, p. 717. In part.

Herdman. Rep. on Tunicata, "Challenger" Reports, vol. vi, pt. xvii, p. 245. In part.

R. von Drasche. Die Synascidien der Bucht von Rovigno, Wien, 1883 , p. 8.

Carus. Prodromus Faun. Mediterr., Stuttgart, 1890, vol. ii, pt. ii, p. 476 .

- Herdman. On the Genus Ecteinascidia and its Relations, with Descriptions of two new Species, and a Classification of the Family Clavelinidæ, Trans. Biol. Soc. Liverpool, vol. v, 1890, pp. 160, 161. 
Body oblong, more or less clavate, not provided with a postabdominal peduncle.

Stolons distinct, delicate and branched.

Professor Herdman has quite recently* subdivided this genus as it was defined in his "Challenger" Report. The difference recognised by Savigny between the types borealis and lepadiformis, in regard to the presence or absence of a well-developed post-abdominal peduncle of test-substance, is raised by him into a criterion of generic value (Podoclavella), while the rudimentary "common test" enclosing the stolons of the "Challenger" species constitutes the salient character of his new genus Stereoclavella. These changes have been rendered desirable by an increase in the number of species and the apparentt distinctness of the three types. As the table in Professor Herdman's paper shows, the restricted genus now includes the species lepadiformis (O. F. Müller), rissoana (M. Edwards; variety only ?), pumilio (M. Edw.), producta (M. Edw.), Savigniana (M. Edw.), and nana (Lahille).

Is not Müller's Ascidia gelatina (Zool. Dan., iv, 26, plate 143) also probably a species of Clavelina?

\section{Clavelina lepadiformis, O. F. Müller. (Pl. II, fig. 1.)}

Ascidia lepadiformis, O. F. Müller. L. c., p. 54, pl. lxxix, fig. 5.

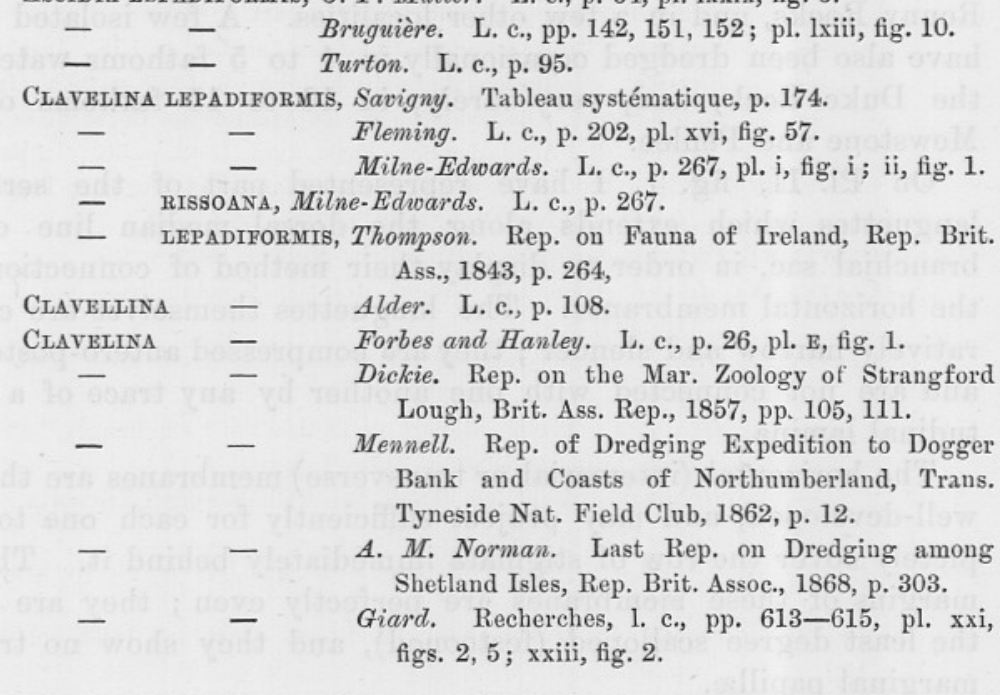

* On the Genus Ecteinascidia, \&c., loc. cit.

+ One of the individuals in Milne-Edwards' figure of Clavelina producta (1. c., pl. ii, fig. 3) exhibits a post-abdominal peduncle of some extent. 
Clavelina lepadiformis, McIntosh. Marine Invertebrates and Fishes of St. Andrews, 1875, p. 54.

Herdman. Fauna of Liverpool Bay, vol. i, 1886, p. 296, and Proc. Biol. Soc. Liverpool, vol. iii, 1889, p. 245.

- $\quad$ - Carus. L. c., p. 476.

Colonies compact, zooids numerous.

Zooids more or less stout, moderately clavate, slightly compressed from side to side, without well-marked external differentiation into thoracic and post-thoracic regions; average height from a half to three-quarters of an inch.

Test gelatinous, perfectly hyaline and transparent.

Thorax one third of the total body-length; œsophageal region short; conspicuous opaque bands of a yellow, brown, or white colour mark the position of the dorsal, ventral and anterior peribranchial sinuses.

Branchial sac with about thirteen transverse rows of stigmata; horizontal membranes broad.

Habits.-Attached to rocks and stones (rarely to algæ and the backs of crabs, Müller) at the bottom of the tidal zone; seldom extending into 10 fathoms water.

At Plymouth fine colonies of this species have been found at extreme low water on the north side of Drake's Island, near the "Bridge" under Mount Edgcumbe Park, in tide-pools among the Renny Rocks, and in a few other localities. A few isolated zooids have also been dredged occasionally in 4 to 5 fathoms water near the Duke Rock, and, very rarely, in 10 to 15 fathoms off the Mewstone and Penlee.

On Pl. II, fig. 1, I have represented part of the series of languettes which extends along the dorsal median line of the branchial sac, in order to display their method of connection with the horizontal membranes. The languettes themselves are comparatively narrow and slender ; they are compressed antero-posteriorly and are not connected with one another by any trace of a longitudinal lamina.

The horizontal (interserial or transverse) membranes are thin but well-developed, and may project sufficiently for each one to completely cover the row of stigmata immediately behind it. The free margins of these membranes are perfectly even; they are not in the least degree scalloped (festooned), and they show no trace of marginal papillæ. 


\section{Pycnoclavella, gen. nov.}

Der.- $\pi v \kappa v o \varsigma$, closely united.

External appearance.-Zooids small and delicate, clavate, arising by slender stalks from a more or less thick, basilar mass of testsubstance.

Body consisting of a small thorax, a slender, often greatly elongate œsophageal region, and a more dilated abdomen, the greater part of which is imbedded in the basilar mass of common test.

Test thin and delicate around the thorax, thicker and firm in the foot-stalks, dense and cartilaginous throughout the basilar mass ; the latter is traversed in all directions by stolonial tubes, some of which even extend and branch in the œsophageal region of the zooids, where they remain sterile or, more rarely, give rise to new buds.

The partial imbedding of the posterior ends of the zooids in a basal mass of test is a character which is common to this genus and the genus Stereoclavella, as recently defined by Herdman (l. c., pp. 160,161); but although this is the only character by which Stereoclavella has been as yet distinguished, a comparison of Pycnoclavella aurilucens with the described species of Stereoclavella shows that marked differences exist between the two genera. In Pycnoclavella the zooids arise by slender stalks from the common basal test, and there is a definite demarcation between the two regions; while in Stereoclavella* it is almost impossible to speak of the common test as a distinct structure. The elegant and regularly clavate form of the free portions of the zooids, together with their delicacy and small size, are also points clearly separating the former genus from the species of Stereoclavella. It appears to me to be very probable that the chief character common to these two genera has been attained independently in each case, Stereoclavella having arisen from a species of Clavelina resembling $C$. lepadiformis in form and size, while Pycnoclavella is more akin to $O$. producta.

\section{Pycnoclavella aurilucens, $s p$. nov. (Pl. II, figs. 2 and 3.)}

Colonies very variable in shape and size, as regards both the thickness and extent of the common test and the length of the free portions of the zooids.

Zooids with thorax slightly compressed from side to side, almost as broad as long, connected with the basal test by a slender cylin-

* The preliminary description given by Professor Herdman of S. australis has no reference to the exact character of its common test. 
drical foot-stalk of varying length ; thorax $\frac{1}{20}$ inch in length ; footstalk from twice to ten times as long. Abdomen elongate, deeply embedded in the common basal test.

Colour.-A band of golden-yellow pigment extends along the ventral side of the thorax and is continued into the œsophageal region; it is absent from the dorsal side; this band gives a conspicuous colouration to the zooids, when seen alive with the naked eye.

Test of a pale green colour, semi-transparent; thin around the thorax, thicker and firm in the œsophageal region, cartilaginous in the basilar mass ; traversed by stolonial tubes in the basal, abdominal, and even œsophageal regions; in the latter region (that of the foot-stalk) the tubes are generally sterile.

Apertures circular, proximate, in the median sagittal plane; branchial terminal, cloacal subterminal.

Branchial sac with seven to nine rows of stigmata; horizontal membranes well developed, broad; dorsal languettes borne on the horizontal membranes, long and stout; endostyle of great size; aperture of hypoganglionic gland simple, circular.

Cardiac structures (pericardium, epicardium) as in Clavelina; pericardium not recurved.

Habits.-Irregularly attached along with masses of Polyzoa (Bugula, Scrupocellaria, \&c.), calcareous sponges (Leucosolenia), and compound Ascidians (Botryllus, Didemnum) to varied objects from rough ground in 10-20 fathoms water (e. g. cases of tubicolous Annelids, Gorgonia stems, shelly débris); rarely forming a thin carpet on the stems of red weeds, such as Delesseria.

I first noticed this beautiful little Tunicate in the winter and early spring of 1889 , when it was dredged several times on rough ground off the Mewstone, on one occasion to the west of it, but generally from half to two miles south or south-west of the rock. This is certainly the best locality for the species at Plymouth, although curiously enough the first specimen was dredged on January 26th in shallower water inside the Breakwater, north-west of the chequered buoy. This first colony was attached to the stem of a Delesseria, and formed a thin crust over its surface, the zooids having very short stalks (see Pl. II, fig. 3) ; the colony was unusually free from adventitious foreign bodies, and the configuration of its parts, especially of the basal test, was much more obvious than in specimens dredged off the Mewstone. These latter colonies are almost inextricably bound up with Polyzoa, Botryllids, Sponges, and other organisms, forming tangled masses in which usually only the brightly gleaming heads of the zooids are visible, the basal test being hidden beneath numerous other organisms and foreign bodies. It is a very 
interesting fact that the stalks of the zooids are elongated in direct proportion to the abundance and height of the foreign organisms competing with them for space and oxygen, resembling in this respect numerous epiphytes and other vegetable growths in a thick Brazilian forest.

If the smaller zooids of a living colony be touched with a needle, the bright yellow thorax frequently withdraws itself completely from the greenish test of that region and disappears within the stalks or below the level of the corm. The larger zooids contract upon irritation, but do not completely withdraw in this way. On contraction they give, as it were, a stoop or bend towards the dorsal side-away from the side with the line of yellow pigment; this is due to the fact that the longitudinal muscle-bundles are somewhat more numerous in the dorsal than in the ventral section of the body. Very rarely, if the irritation be continued, the larger zooids may also behave like the smaller ones.

Since I made these experiments with Pycnoclavella I have found that Forbes and Goodsir* noticed a precisely similar reaction in the case of their Syntethys hebridicus. Indeed, there are several interesting resemblances between the genera Diazona (Syntethys) and Pycnoclavella, the chief of which I may mention as being the greenish colour of the test and the embedding of the abdominal regions of the zooids in a thick basal mass of common test, the thoracic portions remaining free; in Diazona this process is more complete than in Pycnoclavella.

With regard to the relations of this species to Clavelina, I have stated above that although there can be no doubt that both Stereoclavella and Pycnoclavella are closely allied to that genus, and, indeed, almost certainly derived from it, I believe others will agree with me that this species is more closely related to Clavelina itself than to the species of Stereoclavella; its nearest ally seems to be MilneEdwards' species Clavelina producta. ${ }^{\dagger}$ This species produces buds from the lateral walls of the abdomen as well as from the basal stolonial tubes, a fact hitherto without parallel in the Clavelinidæ. Pycnoclavella aurilucens, however, exhibits occasionally the same phenomenon (see Pl. II, fig. 2), and there can be little doubt that the stolonial tubes traversing the foot-stalks in this species, whether they remain sterile or produce buds, are the direct homologues of the fertile stolonial tubes of the abdominal walls in Clavelina producta. The only other "social Ascidian" possessing morphologically similar structures is Sluiteria rubricollis (Van Beneden $\ddagger$

* Trans. Roy. Soc. Edin., xx, 1853, p. 308.

† Milne-Edwards' Observations, l. c., p. 267, pl, ii, fig. 3.

¥ E. van Beneden, Les genres Ecteinascidia, Rhopalæa et Sluiteria; note pour servir à

Ascrdia, Fleming. Molluscous Animals, Edin., 1837, p. 202

Perophora, Fórbes and Hanley. Brit. Moll., 1853, p. 28.

- $\quad$ Adams. Genera of Mollusca, 1858, ii, p. 596.

Giard. Recherches, l. c., p. 615.

R. von Drasche. Die Synascidien, 1883, p. 8.

Herdman. Tunicata, Encycl. Brit., 9th edit.

- Carus. Prodr. Faun. Med., 1890, ii, pt. ii, p. 476.
- Herdman. On the Genus Ecteinascidia, l. c., p. 161.

Zooids quadrangular or oblong, rarely pyriform, never cylindrical, generally compressed from side to side.

Test thin, membranous, without sterile stolonial tubes; apertures apart.

Branchial sac rarely provided with rudimentary horizontal membranes; interserial papillæ triangular or tubular ; papillæ simple or 
and Sluiter), whose transparent test is traversed by several sterile stolonial tubes, branching dichotomously and terminating in a few delicate papillary prolongations on its surface.

These three species illustrate the probable manner in which the "vessels of the test" in Ascidiidæ arose phylogenetically; at first few, short and completely fertile (e.g. Clavelina producta), they subsequently increased somewhat in number and extent, dividing dichotomously in the thickness of the test, and became less fertile (e.g. Pycnoclavella aurilucens); at a still later stage (represented by Sluiteria rubricollis) the tubes became completely sterile, and, though still not numerous, were essentially organs of the test. The loss of the power of blastogenesis altogether would now bring us to the stage occupied to-day by the species of Ciona; while an increase in the number of the vessels would lead to the condition found in the greater number of simple Ascidians.

It is interesting to note also that these forms furnish confirmatory evidence of the view enunciated by Della Valle* that the sterile ectodermic tubes of the test have essentially a "palliogenic" function. In Pycnoclavella aurilucens the part of the test traversed by them is much thicker and firmer than the thoracic portion, and in Shiteria rubricollis the test is, according to Van Beneden, thicker and more resistant than in Ecteinascidia. The test of "social Ascidians" generally is characteristically thin and soft, and this can be referred directly to the absence or very slight development of sterile "palliogenic" tubes. The softness and delicacy of the test of Ciona as compared with that of Ascidia is also a further confirmation of Della Valle's view.

A fully illustrated account of the anatomy of Pycnoclavella will appear in another journal later in the year, and with it will be published coloured sketches of the living colony.

\section{Family 2.-PEROPHORID五.}

Body undivided into thorax and abdomen; viscera on the left side of the branchial sac.

Test transparent, for the most part thin and membranous, rarely traversed by a few sterile stolonial tubes; never investing the stolons in a common basal sheath; apertures generally well apart, the branchial terminal and the cloacal dorsal, lobed, or rarely proximate, terminal and only indistinctly lobed.

la classification des Tuniciers, Bull. Acad. Roy. des Sci., \&c., Bruxelles (iii), xiv, 1887, pp. 43,44 .

* See Arch. Zool. Exp., x, 1882, Notes et Revue, p. xli. 
Musculature consisting almost exclusively of transverse fibres; longitudinal fibres rarely present except around the apertures.

Branchial sac not folded, horizontal membranes absent or feebly developed, replaced or surmounted by interserial rows of papillæ; papillæ simple and unbranched or supporting incomplete or complete internal longitudinal bars; bars papillate or not papillate; dorsal lamina a longitudinal membrane or represented by a series of slender languettes; languettes rarely compressed from before backwards ; stigmata straight.

Tentacles simple, filiform.

Genitalia in the loop of the intestine; oviduct and vas deferens present.

Reproduction by gemmation as well as from ova.

This family includes the genera Perophora (Wiegmann), Perophoropsis (Lahille), Sluiteria (E. van Beneden), and Ecteinascidia (Herdman, sens. strict.). In a complete system of classification it should be placed very near to Roule's group "Phallusidées," which embraces the genera Ascidiella, Ascidia, and Phallusia.

A species of Ecteinascidia (E. Moorei), quite recently described by Herdman, appears from his figures to possess dorsal languettes flattened antero-posteriorly, and this is implied, though not directly stated, in the text of his paper. This condition of the languettes is unique within the family, and affords an approach towards the genera Rhopalopsis, Rhopalæa, \&c.

\section{Perophora, Wiegmann.}

Ascidia, Lister. Some Observations on the Structure and Functions of Tubular and Cellular Polypi and of Ascidiæ, Phil. Trans., pt. ii, 1834, pp. $378-382$.

Perophora, Wiegmann. Jahresbericht, Archives, 1835, p. 309.

Ascidia, Fleming. Molluscous Animals, Edin., 1837, p. 202.

Perophora, Fórbes and Hanley. Brit. Moll., 1853, p. 28.

- Adams. Genera of Mollusca, 1858, ii, p. 596.

- Giard. Recherches, l. c., p. 615.

- R. von Drasche. Die Synascidien, 1883, p. 8.

- Herdman. Tunicata, Encycl. Brit., 9th edit.

- Carus. Prodr. Faun. Med., 1890, ii, pt. ii, p. 476.

- Herdman. On the Genus Ecteinascidia, l. c., p. 161.

Zooids quadrangular or oblong, rarely pyriform, never cylindrical, generally compressed from side to side.

Test thin, membranous, without sterile stolonial tubes; apertures apart.

Branchial sac rarely provided with rudimentary horizontal membranes ; interserial papillæ triangular or tubular ; papillæ simple or 
each provided near its extremity with an anterior and posterior longitudinal process; processes rarely fusing to form complete internal longitudinal bars; dorsal lamina, a rudimentary or welldeveloped longitudinal membrane, supporting interserial languettes compressed from side to side.

Stigmata usually in four, rarely six, transverse rows.

Stolons delicate, distinct, creeping; branches generally alternate in position.

The species included within this genus are at present four in number -Listeri (Wiegmann), Hutchinsoni (Macdonald), viridis (Verrill), and banyulensis (Lahille). Of these, $P$. banyulensis may prove not to be distinct from $P$. viridis, as Herdman believes, while $P$. Hutchinsoni, despite Macdonald's careful description and figures, will probably be found on re-examination to present some structural characters not included in the above generic diagnosis.

In his recent paper on Ecteinascidia and its allies, Professor Herdman has anticipated me in a description of the interesting condition of the interserial papillæ in $P$. viridis. I can quite confirm his account by my observations on a number of specimens of a Perophora which Professor Weldon collected in the Bahamas and gave into my hands some time ago for description. Professor Herdman rightly interprets the bifid or trifid papillæ of $P$. viridis as " rudimentary or imperfect internal longitudinal bars," but so far, I believe, no perfect bars have been discerned in the branchial sac of Perophora. In some specimens, however, sent to me from the Zoological Station at Naples, and labelled "Perophora Listeri" I discovered some months ago that numerous perfect internal longitudinal bars actually existed, being supported upon the ends of flat triangular " connecting ducts" precisely as in Rhopalopsis crassa or Ecteinascidia Moorei, with this difference only, that small papillæ were frequently present at the points of junction. The existence of papillæ on the bars renders the affinity between Perophora and Sluiteria still closer than has been already believed. It is very probable that a new species must be created for the Naples type, but that is a matter to which I hope to refer in a subsequent paper on the anatomy and variation of the genus. (See Postscript, p. 64.)

\section{Perophora Listeri, Wiegmann. (Pl. II, figs. 4, 5, 6.)}

Ascidia, sp., Lister. Phil. Trans., 1834, pp. 378-382, pl. xi.

Perophora Listeri, Wiegmann. Archives, 1835, p. 309.

Ascidia, n. sp., Fleming. Moll. Anim., 1837, pp. 202-209, pl. xvii, fig. 59 (2).

Prrophora Listeri, Forbes and Hanley. L. c., p. 28, pl. e, fig. 2.

- - Giard. Recherches, l. c., pp. 615, 616, pl. xxi, figs. 3, 6 to 11,13 to 15, pl. xxiv. 
Perophora Listeri, Herdman. Second Report, Proc. Biol. Soc. Liverpool, iii, 1889 , p. 246.

- $\quad$ Herdman. On the Genus Ecteinascidia, l. c., pp. 158-161.

Zooids quadrangular, compressed from side to side, colourless, transparent.

Apertures widely separated, branchial with six lobes, cloacal with five.

Tentacles forty in number, of three sizes.

Branchial sac always provided with unbranched digitiform or slightly triangular interserial papillæ; no rudiments of internal longitudinal bars; rudimentary horizontal membranes; stigmata in four transverse rows, two between each pair of interserial papillæ.

Musculature feebly developed; transverse fibres few, widely separate from one another, extending from the dorsal region to the middle of each side; also forming a weak sphincter round each aperture ; longitudinal fibres almost as well developed as the transverse, extending from the oral sphincter as far as the level of the first interserial bar of the branchial sac ; several longitudinal fibres arising anteriorly between the oral aperture and the anterior end of the endostyle, extending with the longitudinal fibres of the oral sphincter to the same distance; longitudinal fibres of the cloacal sphincter short.

Habits.-Attached to stones or algæ in shallow water.

At Plymouth Perophora Listeri has been dredged in the estuary of the Yealm, and in 4 to 5 fathoms water off the Duke Rock. $\mathrm{Mr}$. Heape recorded it as abundant on the rocks below the Hoe.

There can be very little doubt that the name given by Wiegmann to Lister's Perophora has been also applied to forms specifically distinct from it. Lister, in his admirable paper, remarks upon the existence of " finger-like processes, about eight in a row, that project nearly at right angles into the central cavity " [of the branchial sac], and these are shown in some of his figures.

Giard also mentions these papillæ and compares them with the papillæ which were figured by Savigny in his account of Diazona violacea. These papillæ are simple and digitiform, so that Giard's species probably did not differ from Lister's with respect to these structures.

On the other hand the species found at Naples and, as I gather from Professor Herdman's paper, at Banyuls also (by Lahille) present considerable differences from this simple arrangement. It is probable, therefore, that Perophora Listeri does not occur in the Mediterranean but is confined to the Atlantic shores of northern Europe.

The condition of the papillæ in Plymouth specimens is shown on 
Plate II, fig. 6, in a drawing taken from preserved material. These structures are seen to have a flattened triangular shape and are connected at their bases by very low and rudimentary horizontal membranes (cf. fig. 7). In life, these papillæ assume a more extended digitiform shape, as Lister long ago stated. If these papillæ were to be connected by internal longitudinal bars (as frequently occurs in the Naples species), meshes would be formed, each containing two stigmata.

The opening of the duct of the hypoganglionic gland (fig. 7, c. v.) is simply circular. It is situated in front of a raised triangular area, whose apex is posterior; this constitutes what is undoubtedly the homologue of the epipharyngeal groove. A precisely similar structure has been figured by Roule for Rhopalæa nepolitana,* and observed in Sluiteria rubricollis by E. van Beneden. $\dagger$ From the posterior apex of this area arises the dorsal lamina (fig. 7, d. l.) as a low membrane which increases slightly in height as it extends posteriorly. At the level of each horizontal membrane it rises up into a curved triangular languette $(l)$, and occasionally there is a small projection from its edge between each pair of interserial languettes (fig. 8, i. p.). An examination of fig. 7 also shows that the horizontal membranes really are continued upon the lateral faces of the dorsal lamina, although they do not extend along the languettes.

The structure of the dorsal lamina in this species approaches closely in essential features that described by van Beneden in Shiteria rubricollis, in which form there is a continuous longitudinal membrane whose border is cut into festoons in correspondence with the number of transverse (interserial) bars. The lamina is provided with fourteen oblique ridges which also correspond in number with the horizontal bars. Although in his diagnosis of the genus Sluiteria, Professor van Beneden denies the presence of horizontal membranes (l.c., p. 43), he admits in his description of S. rubricollis that the connecting ducts of the internal longitudinal bars "spring by an enlarged base from little interserial folds traversing the length of the transverse bars" (p. 34). This is precisely the condition I have found in the Naples Perophora, and it is essentially similar to what is here described for P. Listeri; interserial membranes are in each case present, but rudimentary. The ridges on the lamina of S. rubricollis are therefore undoubtedly of the same nature as the less conspicuous elevations formed in $P$. Listeri by the continuation of the horizontal membranes upon the sides of the lamina (see fig. 7).

* Roule, Rev. des Esp. de Phallusiadées de Provence, Rec. Zool. Suisse, iii, pl. xiv, fig. 14 .

† Ed. van Beneden, Sur les genres Ecteinascidia, \&c., 1. c., p. 35. 
Further the lamina of Sluiteria rubricollis is described as being enrolled, the concavity being to the right; my figure also shows that the marginal languettes of $P$. Listeri are bent over in a precisely similar way.

In Ecteinascidia turbinata (Herdman) and diaphanis (Sluiter) the dorsal lamina is represented by tentacular languettes unconnected by a longitudinal membrane. This membrane is present in E. Thurstoni (Herdman), while horizontal membranes are quite absent, and with them also every trace of interserial ridges on the sides of the dorsal lamina. In E. Moorei (Herdman) all the horizontal structures are well developed, but the longitudinal lamina is absent.

\section{Family 3.-DIAZONID A.}

Body large, consisting of a thorax and abdomen connected by a slender, more or less elongate œsophageal region; stolonial tubes arising from the posterior end of the abdomen.

Test gelatinous or semi-cartilaginous, greatly developed around the basal stolonial tubes, with formation of a thick common test, in which the abdominal portions or the entire bodies of the zooids are imbedded; apertures terminal, each divided into six lobes, rarely smooth.

Musculature consisting of both longitudinal and transverse fibres, which for the most part anastomose freely ; longitudinal fibres especially well developed.

Branchial sac large; with or without festooned horizontal membranes; interserial papillæ always present, supporting complete or rudimentary internal longitudinal bars; longitudinal bars not papillate; dorsal lamina represented by a series of languettes with long tapering ends; dorsal tubercle a large, longitudinally ovate slit surrounded by broad raised margins; branchial sac not folded.

Heart recurved upon itself.*

Genitalia in the loop of the intestine, or extending considerably behind it ; oviduct present or absent.

Reproduction by gemmation as well as from ova, with formation of colonies of great size; colonies without systems.

This family, including the genera Diazona (Savigny) and Tylobranchion (Herdman), has relations both with the Cionidæ, Distomidæ, and Polyclinidæ. To Lahille belongs, I believe, the credit of first emphasizing the resemblances between Diazona and Tylobranchion, the latter being one of the most interesting of the "Challenger" forms made known to us by Professor Herdman's researches. As

* This has not yet been established for Tylobranchion, but is probably the case. 
I gather from Professor Herdman's remarks upon Lahille's system of classification, this zoologist groups together, along with Diazona and Tylobranchion, the genera Ecteinascidia, Rhopalæa, and Ciona. I believe, however, that Ecteinascidia is much more closely related to Sluiteria than to any of these genera, and while Roule has established the relationship of Rhopalæa and Ciona beyond doubt, the equally close affinity of Diazona to these forms is still a matter of some uncertainty. That the mere formation of a huge common mass of test enclosing the abdominal regions of the zooids is not of itself a point of great systematic importance is demonstrated by Pycnoclavella, which is in every other structural respect a true Clavelina. Therefore on this head I am quite in accord with Lahille in his efforts to break up the group "Ascidiæ compositæ," and to classify the Ascidians upon morphological grounds only or in the main. Yet I cannot but regard the definite position of Diazona and Tylobranchion among the Cionidæ as too forcible a disregard of the ties which also bind them to the Polyclinidæ and Distomidæ.

\section{Diazona,* Savigny.}

Diazona, Savigny. Tableau systématique, l. c., pp. 174, 175.

- Dujardin, in Lamarck. Hist. Nat. des Anim. sans Vertèbres, 2nd ed. (par Deshayes and M. Edwards), t. iii, 1840, pp. 498, 499.

Synmethys, Forbes and Goodsir. On some Remarkable Marine Invertebrata new to British Seas, Trans. Roy. Soc. Edin., xx, 1853, p. 307.

- Forbes and Hanley. Brit. Moll., iv, p. 244.

Dinzona, Alder. Observations on British Tunicata, Ann. and Mag. of Nat. Hist. (iii), xi, 1863, p. 169 .

- Lahille. Comptes Rendus, cii, 1886, p. 1574, and civ, 1887, p. 240.

- Giard. Comptes Rendus, ciii, 1886, pp. 755, 756.

- R. von Drasche. Die Synascidien, p. 8.

- Carus. Prodr. Faun. Med., 2, ii, p. 480.

Colony gelatinous, sessile; the zooids superior, their thoracic portions freely projecting.

Musculature with longitudinal fibres united into well marked bundles.

Branchial sac with festooned horizontal membranes, supporting complete, rarely incomplete, internal longitudinal bars, not papillate at the point of junction; dorsal languettes triangular, compressed from before backwards.

Genitalia in the loop of the intestine; oviduct (always?) and vas deferens present.

* I greatly regret that my efforts to obtain a copy of Della Valle's Contribuzioni have been unsuccessful up to the time of going to press, and I must express the same regret with regard to Lahille's Recherches sur les Tuniciers. 
In 1853 Professors Forbes and Goodsir announced the discovery of a composite Tunicate allied to Savigny's Diazona violacea, but differing from it in the possession of the following characters: Plain undivided orifices, non-pedunculated abdomen, meshes with " one ciliated opening" only, and apple-green colour. Their genus Syntethys was established upon these grounds, but Alder subsequently wrote to show the generic identity of the two forms, basing his criticisms upon an examination of specimens dredged near Guernsey and possibly upon a re-examination of a portion of one of the original specimens of Forbes and Goodsir. Alder satisfactorily showed that the difference of colour was one due entirely to the action of the spirit used in preservation, and also that the pedunculation of the abdomen is very variable in its extent. He also noted that, after preservation, the division of the apertures into lobes was generally difficult to make out. His conclusion in regard to the generic identity of Diazona violacea and the so-called Syntethys is probably correct, although, as I shall endeavour to show below, his identification of the Guernsey species with that of Forbes and Goodsir from the Hebrides is extremely doubtful.

\section{Diazona violacea, Savigny. (Pl. II, figs. 7, 8.)}

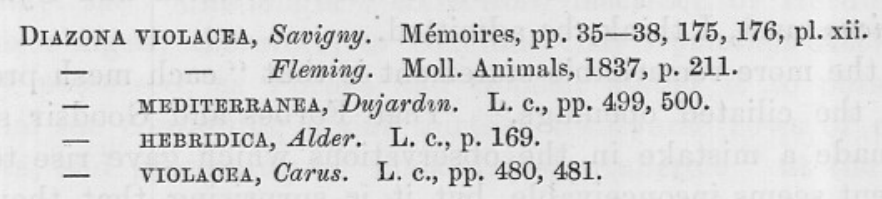

Colony massive, irregularly rounded, attached by a short, thick pedicle or base; total diameter about 7 inches, total height 5 or 6 inches ; of apple-green colour when alive, semi-transparent.

Zooids often 2 inches long, with oral and cloacal orifices each six-rayed.

Branchial sac with sixty to eighty transverse rows of stigmata; meshes each containing three, rarely four stigmata ; internal longitudinal bars for the most part completely formed, but here and there represented by $T$-shaped interserial papillæ, as in Tylobranchion; dorsal tubercle a large deep groove, elongate anteroposteriorly, with thickened walls.

Habits.-Attached to rocks or stones in deep water.

Dredged at Plymouth on rough ground off Stoke Point, and off the Eddystone in 20-40 fathoms of water.

There are two remarkable statements in the original description of the structure of Syntethys Hebridicus by Forbes and Goodsir

there might be between this form and the Diazona violacea so admirably described by the great French anatomist. His researches were not very fruitful of result: "The only difference I can find is that the papillæ of the branchial sac in the latter (Syntethys Hebridicus) are stout and obtuse, very different from the slender pointed form represented by Savigny; I have therefore determined to consider them distinct until further observations decide the point."

Now Alder's Guernsey specimens are certainly identical (specifically) with the forms investigated by myself, and they are both from practically the same region of the English Channel; there is further no appreciable difference between the Plymouth forms and

* Herdman, "Challenger" Report, vol. xiv, pt. xxxviii, p. 155.

NEW SERIES.-VOL. II, NO. I. 
which have not, to my knowledge, received the attention which they deserve. They are involved in the following account given by these naturalists of the branchial sac in their specimens :

"Branchial chamber with thirteen transverse rows of oblong openings, fringed with ciliated epithelium; hooked fleshy tubercles at the intersections of the branchial meshes, each mesh presenting one of the ciliated openings ; the tubercles give the internal surface of the chamber a dotted appearance." (Trans. Roy. Soc. Edin., 1853, p. 307, cf. also Forbes and Hanley, l. c., p. 244.)

Now, in the specimens of Diazona violacea dredged at Plymouth, the number of transverse rows of stigmata greatly exceeds that given by the eminent naturalists who described Syntethys Hebridicus; the number is usually about sixty, seventy, or even more! Further, the stigmata in each mesh are invariably three or four, the latter number agreeing with the description and figure given by Savigny.

Were Professors Forbes and Goodsir mistaken? Such a theory is unlikely, for one of their figures (l. c., pl. ix, fig. 4 d) shows in outline some of the appearances which they recorded in the words quoted above. Indeed, this figure is too precise to admit of any doubt as regards the approximate number of transverse bars (and, therefore, rows of stigmata) in their specimens, and a difference in this respect between Diazona violacea and Syntethys Hebridicus must, I think, be admitted:

But the more remarkable statement is that "each mesh presents one of the ciliated openings." That Forbes and Goodsir should have made a mistake in the observations which gave rise to this statement seems inconceivable, but it is surprising that they pass no reflection upon so unusual a condition of the branchial sac. There was plainly no error in the identification of the "meshes," for "hooked fleshy tubercles" are stated to be present at the "intersections of the branchial meshes" (a somewhat confused but quite intelligible statement). Still, the fact of one stigma alone being included in each mesh has either to be accepted or explained away.*

It is conceivable that the appearance of one "ciliated opening" corresponding to each mesh was due to a great transparency of the "trame fondamentale" of the branchial sac, and that while the meshes were observed, the true stigmata were not noticed; but I cannot reconcile this hypothesis with the assertion, so definitely made, that the "oblong openings" were "fringed with ciliated epithelium." It is also impossible, and for the same reason, to imagine that the

* This condition exists in Polyclinum sabulosum (Lahille, Comptes Rendus, cii, p. 1574), and is approached in Tylobranchion speciosum. 
meshes were totally devoid of stigmata, as in Pharyngodictyon mirabile of the "Challenger" collection, described by Herdman.*

I am obliged, therefore, to conclude that Syntethys Hebridicus actually possessed, as Forbes and Goodsir stated it to possess, a branchial sac containing about thirteen transverse rows of oblong stigmata, and presenting a "hooked fleshy tubercle" at the junction of every longitudinal and horizontal bar.

It should be noticed that in the original description there is nothing irreconcilable with the view that the branchial sac of Syntethys Hebridicus may in reality have been quite destitute of true internal longitudinal bars, and possibly of horizontal membranes; the "hooked fleshy tubercles" may have been such rudimentary connecting ducts and bars as Herdman has described and figured for Tylobranchion speciosum (l. c., p. 161). In this connection I may state that I find the internal longitudinal bars of Diazona violacea to be by no means rarely incomplete in portions of the branchial sac; they are then represented by structures which could well be described as " hooked fleshy tubercles."

I will not maintain that this new view of Forbes and Goodsir's very "remarkable invertebrate" is probable, but it is at least possible. If it should prove eventually to be correct, a very interesting connection between Diazona violacea and Tylobranchion speciosum will have been established.

By admitting the above-named differences between the branchial sacs of Diazona violacea and Syntethys Hebridicus, it will be noticed that I do not accept Alder's identification of his Guernsey specimens of Diazona with Forbes and Goodsir's species. From Alder's account I have been led to believe that he assumed this identity too hastily. He states that his specimens were " at once recognised as the Syntethys Hebridicus of Forbes and Goodsir," and upon this assumption he endeavoured to find out what structural differences there might be between this form and the Diazona violacea so admirably described by the great French anatomist. His researches were not very fruitful of result: "The only difference I can find is that the papillæ of the branchial sac in the latter (Syntethys Hebridicus) are stout and obtuse, very different from the slender pointed form represented by Savigny; I have therefore determined to consider them distinct until further observations decide the point."

Now Alder's Guernsey specimens are certainly identical (specifically) with the forms investigated by myself, and they are both from practically the same region of the English Channel; there is further no appreciable difference between the Plymouth forms and

* Herdman, "Challenger" Report, vol. xiv, pt. xxxviii, p. 155.

NEW SERIES.-VOL. II, NO. I. 
Fig. 2.

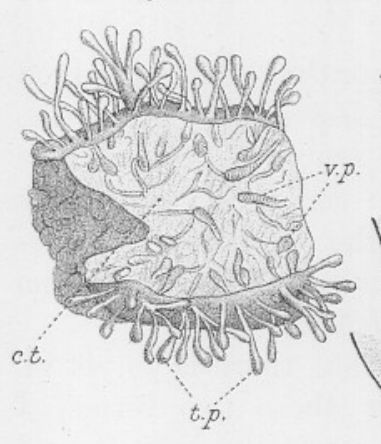

Fig. 4.

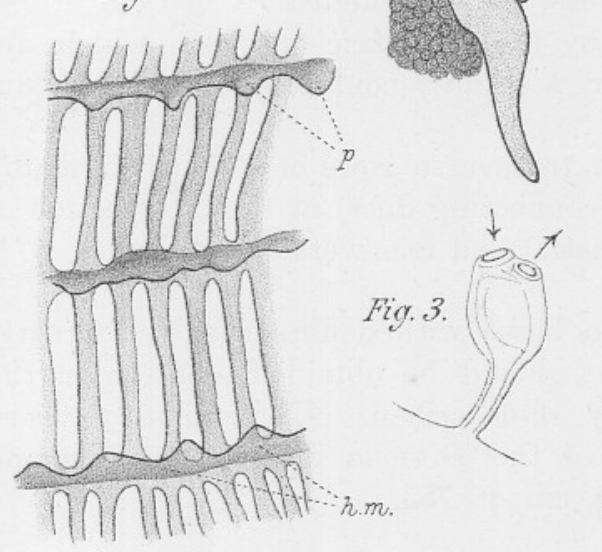

Fig. 1.

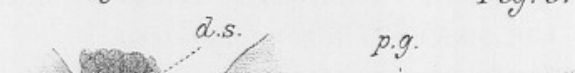

Fig. S.
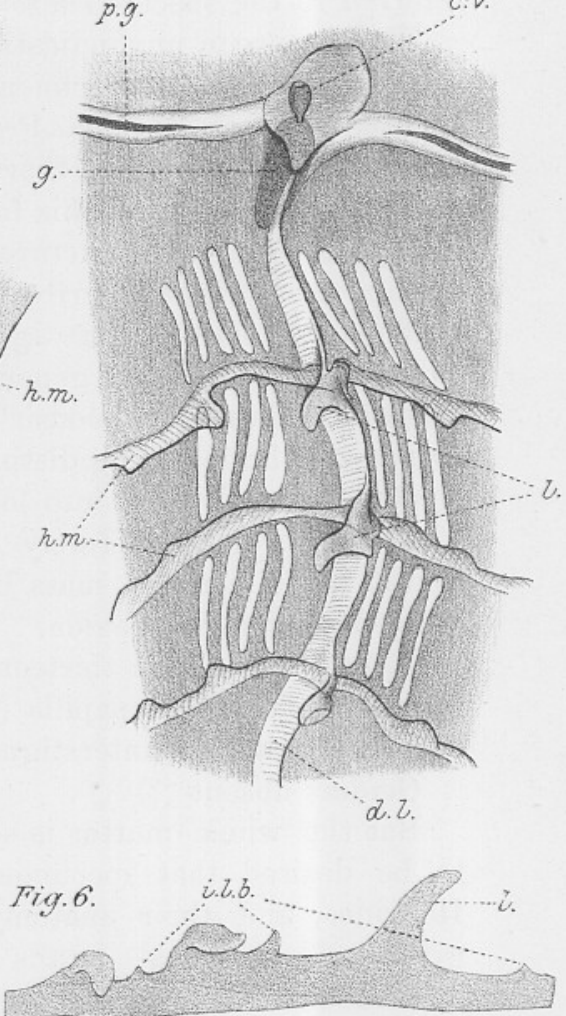
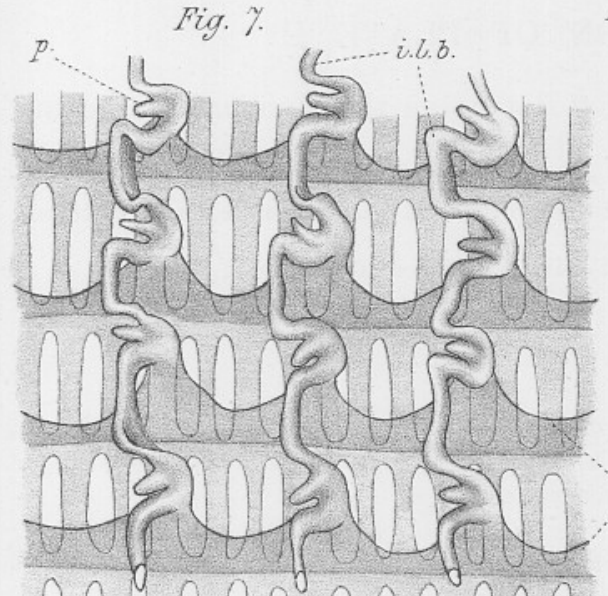

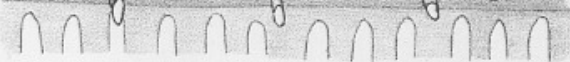

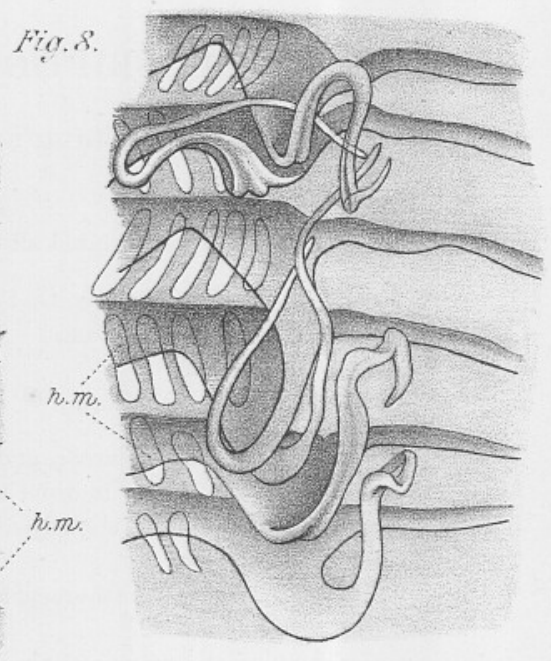


Savigny's species. Therefore Alder's examples must also be referred to the species Diazona violacea.

The absence of any indication in Alder's paper that he re-examined the "portion of a specimen (of Syntethys Hebridicus) from the original habitat" which Professor Goodsir sent to him, renders intelligible what would otherwise have been a very strange omission on his part. I refer to his failure to notice the remarkable discrepancy between the structure of the branchial sac in the Channel specimens and that described for Syntethys Hebridicus.

Thus, although I quite agree with Alder that there is as yet no sufficient ground for generically separating these two forms, I believe Forbes and Goodsir's species to be perfectly distinct and to possess the following distinguishing characters :

Orifices not divided into lobes, evenly rounded.

Zooids projecting freely by their thoracic portions, which are united to the common mass by a slightly contracted but not pedunculated œsophageal region.

Branchial sac with thirteen transverse rows of oblong stigmata; a hooked interserial papilla (connecting duct) at the intersection of every longitudinal (interstigmatic) and transverse bar.

Oviduct absent (?)

But the whole matter is so beset with doubts that it is greatly to be desired that specimens should be obtained again from the Hebrides, and their anatomy re-described. Unfortunately Giard gives no anatomical details of the Diazona dredged by him and described in Comptes Rendus, ciii, p. 755.

\section{DESCRIPTION OF PLATE II.}

Illustrating Mr. W. Garstang's " Report on the Plymouth Tunicata," pt. 1.

N.B.-Where not otherwise stated all the figures were drawn from preserved material.

Fıg. 1.-Clavelina lepadiformis, O. F. Müller. Three of the dorsal languettes of the branchial sac. Zeiss, A, Oc. 2, Cam.

d.s. $=$ Dorsal sinus.

$h . m .=$ Horizontal membrane.

Fig. 2.-Pycnoclavella aurilucens, gen. et sp. nov. Portion of a colony. A section has been taken through the colony in order to show the common test and the imbedded portion of the zooids. Nat. size; slightly diagrammatic.

c.t. $=$ Common test.

t.p. $=$ The free portions (thoracic and œsophageal) of the zooids projecting from the common test.

$v \cdot p .=$ The visceral portions of the zooids imbedded in the common test. 
Fig. 3.-Pycnoclavella aurilucens, gen. et sp. nov. The free portion of a zooid from a colony growing on the stem of a Delesseria. Drawn from life, enlarged.

FIG. 4.-Perophora Listeri, Wiegmann. Portion of the branchial sac. Zeiss, A, Oc. 2, Cam. luc.

$h . m .=$ Rudimentary horizontal membranes.

$p .=$ Interserial papillæ (= rudimentary connecting ducts).

FIG. 5.-Perophora Listeri, Wiegmann. Dorsal wall of pharynx, showing dorsal lamina and aperture of hypoganglionic gland, seen from inside. Zeiss, A, Oc. 2, Cam. luc.

$p . g .=$ Pericoronal groove.

c.v. = Ciliated vesicle, opening on the surface of a shield-shaped pad.

$g .=$ Ganglionic mass.

d.l. = Longitudinal membrane of dorsal lamina.

$l .=$ Marginal languettes.

$h . m .=$ Rudimentary horizontal membranes.

Fig. 6.-Perophora Listeri, Wiegmann. Dorsal lamina of another individual, seen from the right side. Zeiss, A, Oc. 2, Cam. luc.

$l .=$ Marginal languettes, interserial in position.

$i . p .=$ Small marginal projections intermediate between the languettes.

Fic. 7.-Diazona violacea, Savigny. Portion of branchial sac, seen from inside. Magnified, slightly diagrammatic.

$h . m .=$ Horizontal membranes.

i.l.b. = Internal longitudinal bars.

$p .=$ Papillw of the connecting ducts. (See Postscript.)

FiG. 8.-Diazona violacea, Savigny. Six dorsal languettes. Zeiss, A, Oc. 2, Cam. luc. h.m. $=$ Horizontal membranes.

Postscript.-By Professor Herdman's kindness I have recently been enabled to consult Lahille's important Recherches sur les Tuniciers. Lahille points out that the appearance of papillæ on the internal longitudinal bars of the branchial sac of Diazona violacea, as previously described by Savigny and Della Valle, is a false one, produced by the thickened remains of the "primitive branchial lauguettes." I had myself, like Alder, failed to find any such vertical papillæ as were represented by Savigny for this species, and was struck by their apparently recumbent position in mounted preparations (see fig. 7); but a reexamination by means of dissecting needles has convinced me that Lahille is quite correct in denying their existence altogether. The necessary correction has been made in the text of my paper, but the diagram given on fig. 7 is in this respect misleading. Lahille also states that the horizontal membranes are very little developed, but this is by no means the case in the Plymouth specimens.

I have stated above (p. 55) that my discovery of internal longitudinal bars in the Naples Perophora will probably necessitate the creation of a new species; but from Lahille's description this species would appear to be identical with his $P$. banyulensis. The Naples species differs widely from $P$. viridis as regards its musculature, a fact which thus militates against Professor Herdman's suggestion that $P$. banyulensis is a synonym of $\boldsymbol{P}$. viridis.

W. G. 